\title{
Cultural, Morphological, Physiological and Biochemical Characteristics of Magnaporthe grisea Isolates of Finger Millet
}

\author{
S. Shanmugapackiam ${ }^{1 *}$, S. Irulandi ${ }^{3}$, P. Murali Sankar ${ }^{2}$, A. Nagaraja ${ }^{3}$ and \\ T. Raguchander ${ }^{1}$ \\ ${ }^{1}$ ICAR - Krishi Vigyan Kendra, Vamban, Pudukkottai - 622 303, India \\ ${ }^{2}$ Department of Plant Pathology, Tamil Nadu Agricultural University, \\ Coimbatore - 641 003, India \\ ${ }^{3}$ Department of Entomology, Tamil Nadu Agricultural University, \\ Coimbatore - 625 601, India \\ ${ }^{4}$ Project Co-ordinating Unit, AICSMIP, GKVK, Bangalore 560 065, India \\ *Corresponding author
}

\section{A B S T R A C T}

\section{Keywords}

Finger millet, Blast disease, Magnaporthe grisea,

Characterization

Article Info

Accepted:

15 July 2019

Available Online:

10 August 2019
A total of 24 blast infected samples were collected from major finger millet growing areas of Tamil Nadu and also from All India Coordinated Small Millets Improvement Project Centres (ICAR) in India. Pathogenicity test with Magnaporthe grisea isolates showed highly significant differences in virulence on the variety KM 252 in the severity of leaf blast. Among the five different media tested, the Oat Meal Agar medium (OMA) was found to be best for the growth of $M$. grisea isolates and all the isolates produced white colony colour. The mean mycelial growth was maximum in OMA medium with $80.12 \mathrm{~mm}$. The temperature $25^{\circ} \mathrm{C}$ and $\mathrm{pH} 6.5$ was found to be ideal for growth, sporulation and mycelial dry weight of $M$. grisea isolates. Of the different carbon sources, Richard's medium with supplemented dextrose recorded the maximum mean mycelial growth of $M$. grisea isolates with $83.74 \mathrm{~mm}$. Among the nitrogen sources, the Richard's medium supplemented with $\mathrm{NaNO}_{3}$ recorded the maximum mean mycelial growth of $85.87 \mathrm{~mm}$. This study was conducted to isolate, identify and characterize the pathogen using cultural, morphological, physiological and biochemical methods.

\section{Introduction}

Finger millet (Eleusine coracana L.) is one of the most important millet crops belonging to the family Poaceae and sub family Chloridoidea (Dida et al., 2008). Among the small millets, finger millet is widely grown traditional grain cereal cultivated in semi-arid areas of East and Southern Africa and South Asia as a stable food for millions of poor population. Finger millet blast caused by Magnaporthe grisea (Hebert) Barr. (anomorph Pyricularia grisea (Cooke) Sacc. is a heterothallic, filamentous fungus, one of the 
major destructive disease causing excessive damage to this crop from seedling to ear head forming stages. The disease occurs during all growing seasons and on almost all finger millet varieties cultivated. $M$. grisea parasitizes over 50 grasses, including economically important crops like wheat, rice, barley and millet (Ou, 1985). Yield loss due to blast can be as high as $50 \%$ when the disease occurs in epidemic proportions. The fungus appears to overwinter as mycelia in the infected living leaves or dead plant debris in the soil (Uddin, 2000). High temperature, high relative humidity and leaf wetness are critical environmental factors in disease development (Ruiz, 2003). The morphological studies of $P$. grisea isolates of finger millet were carried out and the isolates showed considerable variation in mycelial growth, pigmentation and conidia production in culture (Gatachew et al., 2014). Asfaha et al., (2015) reported that rice blast $P$. oryzae isolates were characterized and identified based on their growth parameters into six isolates viz., Po12, Po28, Po41, Po55, Po72 and Po85. Among the four culture media (oat meal agar, rice flour agar, malt extract agar and potato agar), the $P$. oryzae isolates showed optimum growth and good sporulation in oat meal agar followed by rice flour agar. Hence, this study was initiated to understand the cultural, morphological, physiological and biochemical requirements for the growth and development of the pathogen, which could serve as an input in disease management to minimize yield loss in finger millet. This study was also undertaken to investigate the effects of growth factors on mycelial growth of $M$. grisea isolates.

\section{Materials and Methods}

\section{Collection and isolation of $M$. grisea}

Field survey was conducted during Kharif in major finger millets growing regions of Tamil Nadu and the blast infected finger millet plant parts viz., either leaf or neck or finger blast infected samples were taken based on the crop stage available at the time of survey. In addition, the blast infected finger millet samples were also received from the All India Coordinated Small Millet Improvement Project (AICSMIP) centres in India. The collected samples were air dried, separately bagged and stored under refrigerated condition at $4{ }^{\circ} \mathrm{C}$ for the isolation of the pathogen. The blast pathogen ( $M$. grisea) from different plant samples collected was isolated by using the standard tissue isolation method [Tuite, 1969]. Blast infected plant tissues were cut into small pieces and washed in sterile water twice and surface sterilized with 0.1 per cent mercuric chloride solution for $30 \mathrm{sec}$. followed by rinsing in sterilized water twice and transferred to plates containing Oat Meal Agar Medium (OMA). After 4 days for obtaining monoconidial isolate, a dilute spore suspension was prepared in sterilized distilled water and plated onto $0.8 \%$ water agar in Petri plates. After 15 days of incubation at $26 \pm$ $1^{\circ} \mathrm{C}$, single germinating conidium was marked under a microscope and transferred to fresh Petri dish containing OMA medium and then the plates were incubated at $26 \pm 1^{\circ} \mathrm{C}$ for 10 days to get monoconidial isolates (Shanmugapackiam et al., 2017).

\section{Pathogenicity of $M$. grisea}

Pathogenicity tests were performed with field collected isolates of $M$. grisea on finger millet susceptible variety KM252 maintained in pots. Highly significant differences were observed among the finger millet isolates based on leaf blast severity scored on a 1-9 scale for recording leaf blast severity developed for Rice blast of IRRI - International Rice Research Institute, Philippines. The scoring for finger blast incidence was carried out at physiological maturity and at harvest. Neck blast incidence was also recorded at physiological maturity and at harvesting. Neck 
and finger infections were observed at the milky or dough stage and expressed as per cent finger and neck blast incidence. Were the incidence of neck blast was recorded by counting the number of peduncles infected in a total number of plants. Finger blast was scored on the basis of percentage of finger infection (number of fingers infected out of the total fingers). Neck blast was recorded by counting the number of peduncles infected from 25 panicles. Finger blast was scored on the basis of percentage of finger infection from the number of fingers infected from 25 panicles (Mackill and Bonman, 1992). Among these, the most virulent pathogenic isolates from leaf, neck and finger blast were chosen for further studies.

\section{Cultural and morphology characteristics of M. grisea}

\section{Effect of different culture media on the mycelial growth of $M$. grisea}

Cultural characters of different isolates collected were studied using five different media viz., Oat Meal Agar (OMA), Richard's Agar Medium, Potato Dextrose Agar (PDA), Host seed extract $+2 \%$ sucrose agar and V8 juice agar.

The medium were melted separately and kept for cooling. Just before solidification the medium was transferred to Petri dishes. Three replications were maintained.

After solidification, the Petri dishes were inoculated with $9 \mathrm{~mm}$ dia circular discs of fungal mat under aseptically in an inoculation chamber sterilized with UV radiation.

The inoculated agar plates were incubated at $25 \pm 1{ }^{0} \mathrm{C}$ for 15 days. Observations on colony colour, margin, pigmentation, surface texture, mycelial growth and sporulation etc., were recorded.
Influence of various temperature on the mycelial growth and sporulation of

\section{M. grisea}

The growth and sporulation of seven virulent isolates of $M$. grisea were studied at various temperatures $\left(15,20,25,30\right.$ and $\left.35{ }^{0} \mathrm{C}\right)$ on OMA medium (Kumar and Singh, 1995) with three replications. A nine $\mathrm{mm}$ mycelial disc was cut from the margin of a ten days old culture and placed aseptically at the centre of each Petri dish $90 \mathrm{~mm}$ containing $20 \mathrm{ml}$ OMA medium and incubated at given temperatures for 15 days. The colony diameter was recorded at 15 days after incubation. Four discs of $9 \mathrm{~mm}$ were scoped out from each replication and transferred to $5 \mathrm{ml}$ sterilized distilled water in a test tube. The test tubes were agitated to detach the conidia from the mycelial surface and filtered through a cheese cloth. The quantification of conidia in a given suspension was done using a haemocytometer.

\section{Influence of $\mathrm{pH}$ on biomass of $M$. grisea}

Fifty $\mathrm{ml}$ of Richard's broth was transferred to $250 \mathrm{ml}$ conical flasks to study the influence of $\mathrm{pH}$ on the mycelial biomass of $M$. grisea isolates. The $\mathrm{pH}$ of the medium as adjusted to different $\mathrm{pH}$ viz., 3.0, 3.5, 4.0, 4.5, 5.0, 5.5, 6.0, 6.5 and 7.0 by adding dihydrogen phosphate citrate acid buffer (Vogel, 1951). Flasks were sterilized at 15 psi for $20 \mathrm{~min}$. After cooling, mycelial disc from seven virulent isolates with $9 \mathrm{~mm}$ diameter was taken from the edge of the 10 days old culture grown separately on OMA and placed in the conical flask aseptically and incubated for 20 days at $25 \pm 1{ }^{\circ} \mathrm{C}$. After incubation, the individual broth cultures were filtered through pre-weight Whatman No. 1 filter paper. For assessment of the biomass (mycelial dry weight), the broth culture was filtered through muslin cloth and the mat collected as transferred on pre-weighed filter paper, dried 
at $40{ }^{\circ} \mathrm{C}$ for $2 \mathrm{~h}$ and then reweighed. The variation in weight was recorded (Hall and Bell, 1961).

Influence of different carbon and nitrogen sources on the mycelial growth of $M$. grisea

The $M$. grisea isolates were tested for carbohydrate and nitrogen utilization using Richards's basal medium [Sucrose (C12H22O11) $50.00 \mathrm{~g}$, Potassium dihydrogen phosphate (KH2PO4) 5.00 g, Potassium nitrate (KNO3) $10.00 \mathrm{~g}$, Magnesium sulphate (MgSO4. 7H2O) 2.50 g, Ferric chloride (FeCl3. 6H2O) $0.02 \mathrm{~g}$, agar $20.0 \mathrm{~g}$ and distilled water (to make up) $1000 \mathrm{ml}$ by replacing the carbon sources with dextrose, maltose, D- fructose, sucrose, glucose and galactose and replacing the nitrogen sources with L- glycine, $\mathrm{KNO}_{3}$, L- arginine, $\mathrm{NaNO}_{3}$, asparagine and peptone by each isolate of $M$. grisea (Otsuka et al., 1957). All the carbon and nitrogen sources were dissolved separately and sterilized at $15 \mathrm{lbs}$ pressure for 20 minutes. By using a sterile cork borer, mycelial disc of $9 \mathrm{~mm}$ diameter was taken from the periphery of actively growing 10 days old pure culture and inoculated in to the Petri plates containing the Richard's medium supplemented with different carbon, nitrogen sources and the plates were incubated at $25 \pm$ $1{ }^{0} \mathrm{C}$ for 15 days. Colony diameter for each $M$. grisea isolate grown on plates was measured after 15 days of incubation. Colony diameters of each $M$. grisea isolate on plates were measured as described above.

\section{Statistical analysis}

The data were statistically analyzed using the IRRISTAT version 92 developed by the International Rice Research Institute Biometrics unit, the Philippines (Gomez and Gomez, 1984). Prior to statistical analysis of variance (ANOVA) the percentage values of the disease index were transformed to arcsine.
Data were subjected to analysis of variance (ANOVA) at two significant levels $(\mathrm{P}<0.05$ and $\mathrm{P}<0.01$ ) and means were compared by Duncan's Multiple Range Test (DMRT).

\section{Results and Discussion}

\section{Collection and isolation of $M$. grisea}

A total of 24 blast infected samples (leaf blast - 9, Neck blast - 13 and Finger blast - 2) were collected from major finger millet growing areas of Tamil Nadu and also from AICSMIP centres of ICAR during Kharif season 2012 and 2013 (Table 1). The pathogen was isolated from the infected leaf, neck and finger portion of the plant based on the infected plant part collected. The pathogen was purified based on single spore isolation method and maintained in Oat Meal Agar (OMA) slants at $4{ }^{\circ} \mathrm{C}$ under refrigerator condition.

\section{Pathogenicity test for $M$. grisea isolates}

Pathogenicity tests revealed that $M$. grisea isolates were able to infect all accessions of finger millet. Among the 24 finger millet blast isolates obtained from eleven locations, the highest leaf blast severity was recorded on KM252 designated as TNLB1 which showed 8.76 grade followed by the isolates TNNB8 (8.68), BIFB13 (8.41), JANB18 (8.16), JALB9 (8.12), MANB23 (8.12) and TNNB7 (8.02). The least severity of 4.77 scale was recorded in ODNB17 followed by TNNB5 (4.87), MANB19 (5.40) and BINB12 (5.43) (Table 2). Among the 24 isolates, seven isolates which showed higher leaf blast severity (more than 8.0 grade) were used for further studies. Similar with the earlier report of Maharaja (2012) who isolated the M. grisea isolates from leaf, neck and finger of ragi plants collected from different places. A similar method was also adopted by Srinivasachary et al., (2002) to prove the pathogenicity of $P$. grisea on rice. The 
isolation technique used in the present study was in concordance with the earlier work of Nagendran (2011) who also used the same technique for the identification of $P$. grisea. The Koch's postulates were also proved in this study as per the procedure followed by $\mathrm{Ou}$ (1985).

\section{Cultural and Morphology characters of $M$.} grisea isolates

\section{Colony characteristics on different culture media}

Significant variation among the colony characteristics of the different isolates were observed in culture plates which were collected from different localities. All the seven isolates grown on five different media were observed for the colony colour, margin, pigmentation, surface texture, mycelial growth and sporulation of $M$. grisea isolates and the results are presented in Table 3. On the OMA medium, the isolates viz., TNLB1, TNNB7, TNNB8, JALB9 and BIFB13 showed white colour whereas the isolates viz., JANB18 and MANB23 recorded light grey and white colour respectively. Among the media tested, the PDA media resulted irregular margin growth in the isolates viz., TNNB7, TNNB8, BIFB13 and MANB23 with brown and dark brown pigmentation. In addition, the host seed extract +2.0 per cent sucrose agar medium showed the same irregular growth in TNNB8 isolate. The Richards agar medium showed grey colour with entire growth and black pigmentation for all the isolates of $M$. grisea. The isolate TNLB1 was velvety in surface texture whereas the other six isolates viz., TNNB7, TNNB8, JALB9, BIFB13, JANB18 and MANB23 were cottony surface texture. The colony of the isolates viz., TNLB1, TNNB8, JALB9, BIFB13 and MANB23 showed good growth whereas other two isolates viz., TNNB7 and JANB18 recorded medium growth. In PDA medium, the colony of the isolates viz., TNLB1, TNNB7, TNNB8, BIFB13, JANB18 and MANB23 was grey colour whereas the isolate JALB9 was white colour. Five isolates viz., TNNB7, TNNB8, JALB9, JANB18 and MANB23 showed black colour pigmentation whereas other two isolates viz., TNLB1 and BIFB13 were brown in colour. The isolates viz., TNNB7, TNNB8, JANB18 and MANB23 were cottony in surface texture whereas the other isolates viz., TNLB1, JALB9 and BIFB13 were velvety in surface texture. Five isolates viz., TNLB1, TNNB7, TNNB8, JANB18 and MANB23 showed medium growth whereas the other two isolates JALB9 and BIFB13 recorded poor growth. Host seed extract +2.0 per cent sucrose agar medium showed olive grey colour growth for the isolates viz., TNNB8, BIFB13, JANB18 and MANB23. Two isolates viz., TNNB7 and JALB9 showed light grey colour and TNLB1 showed white colony growth. There was entire growth of margin were observed with black pigmentation for all the isolates. The isolates viz., TNNB7, TNNB8, JANB18 and MANB23 were cottony in surface texture whereas, TNLB1, JALB9 and BIFB13 showed velvety in surface texture. All the isolates of $M$. grisea recorded good growth except three isolates viz., TNLB1, JALB9 and BIFB13 showed medium growth. In v8 juice agar medium, the colony of the isolates viz., TNNB8, JALB9, BIFB13 and JANB18 showed light grey in colour whereas, the isolates viz., TNLB1, TNNB7 and MANB23 were grey in colour. The colony of all the isolates was entire in margin, black in pigmentation. The colony of isolates viz., TNLB1, TNNB8, BIFB13, JANB18 and MANB23 was cottony in surface texture whereas the isolates viz., TNNB7 and JALB9 were velvety in surface texture. Five isolates viz., TNLB1, TNNB7, JALB9, BIFB13 and MANB23 showed good growth and other two isolates namely TNNB8 and MANB18 recorded medium growth. This result was in agreement with the earlier work of Meena 
(2005) who studied the mycelial growth and colour of the colony on oat meal agar, host seed extract $+2 \%$ sucrose agar, potato dextrose agar and richard's agar medium. They reported the colony colour of $P$. grisea isolates of rice was buff with good growth, greyish black with medium growth, raised mycelial growth with smooth colony margin and raised mycelium with concentric ring pattern. Mijan Hossain (2000) reported the same kind of results on the growth and colour of the colony of $P$. grisea isolates from finger millet and rice. Similar variations on cultural characters on $P$. grisea isolates were reported by $\mathrm{Ou}$ (1985). The colour difference observed in this study between the segments might be due to the stages of the spores on the different patterns of growth. Getachew et al., 2014 reported that the isolates $M$. grisea showed considerable variation in mycelial growth, pigmentation and conidia production.

Effect of different solid media on the mycelial growth of $M$. grisea isolates

The results revealed that there is a considerable variation among the colony diameter of the $M$. grisea isolates on different solid media (Table 4). The mean of radial growth of various isolates on different solid media reveled that OMA recorded the maximum mean mycelial growth of $80.12 \mathrm{~mm}$ followed by Richards's agar with $76.11 \mathrm{~mm}$, Host seed extract +2.0 per cent sucrose agar with $75.87 \mathrm{~mm}$, V8 juice agar with $75.10 \mathrm{~mm}$ and PDA with $72.52 \mathrm{~mm}$. In OMA, among the seven isolates tested the maximum mycelial growth was observed in TNNB8 with 86.00 $\mathrm{mm}$ followed by the isolates viz., TNLB1 and JALB9 with $85.00 \mathrm{~mm}$ and $83.00 \mathrm{~mm}$ respectively. In case of Richard's agar medium, the isolate TNNB8 recorded the maximum mycelial growth of $81.80 \mathrm{~mm}$ followed by TNLB1and MANB23 with 80.20 $\mathrm{mm}$ and $79.80 \mathrm{~mm}$ respectively. In Host seed extract +2.0 per cent sucrose agar medium maximum mycelial growth was observed in TNNB8 with $84.20 \mathrm{~mm}$ followed by JALB9, TNLB1 and JANB18 with $81.80,81.20$ and $75.00 \mathrm{~mm}$ respectively. In V8 juice agar medium, maximum mycelial growth was observed in TNLB1 with $84.30 \mathrm{~mm}$ followed by JALB9, JANB18 and TNNB8 with 84.20, 78.00 and $77.60 \mathrm{~mm}$ respectively. In PDA medium maximum growth was observed in TNLB1 with $82.60 \mathrm{~mm}$ followed by TNNB8 and JALB9 with $81.70 \mathrm{~mm}$ and $81.00 \mathrm{~mm}$ mycelial growth, respectively. Similarly, Susan and Ambika (2011) reported that the vegetative mycelial growth of $P$. grisea isolates was high in V8 agar (V8A), potato dextrose agar (PDA) and oat meal agar (OMA). Similar results were also reported by Afshana et al., (2011) and indicated that the OMA was suitable for growth of $P$. oryzae. Subsequently, Khadka et al., (2012) reported that the peptone agar and OMA media were found to be the effective media for mycelial growth and sporulation of $M$. grisea isolates of rice and finger millet. This is also in accordance with Getachew et al., (2014) observed that the OMA medium favoured the growth of $P$. grisea much more than PDA medium. Recent findings have also confirmed that the oat meal agar was the best medium for the growth and sporulation of $P$. oryzae (Asfaha et al., 2015).

\section{Spore morphology of $M$. grisea isolates}

The morphological characteristics of seven isolates of $M$. grisea on OMAwere observed. The results revealed that all the conidia in each isolate were pyriform in shape, hyaline to pale olive colour. The number of spores varied from $1 \times 10^{+5}$ to $6.0 \times 10^{+5}$ conidia $\mathrm{ml}^{-1}$. The length and width of the spore also varied in different isolates of $M$. grisea. Maximum mean spore size of 21.91 x $7.42 \mu \mathrm{m}$ was observed in the isolate TNNB8 followed by TNLB1 and JANB18 with $19.45 \times 7.60 \mu \mathrm{m}$ and $18.32 \times 6.49 \mu \mathrm{m}$ respectively (Table 5). 
Table.1 Collection of isolates of M. grisea from different regions of India

\begin{tabular}{|c|l|l|l|c|c|}
\hline S. No. & Isolates & \multicolumn{1}{|c|}{ Location } & \multicolumn{1}{|c|}{ States } & Plant parts & Leaf \\
\hline $\mathbf{1}$ & TNLB1 & Krishnagiri & Tamil Nadu & Leaf & CO14 \\
\hline $\mathbf{2}$ & TNLB2 & Krishnagiri & Tamil Nadu & Leaf \\
\hline $\mathbf{3}$ & TNLB3 & Dharmapuri & Tamil Nadu & Leaf & CO14 \\
\hline $\mathbf{4}$ & TNLB4 & Coimbatore & Tamil Nadu & Neck \\
\hline $\mathbf{5}$ & TNNB5 & Krishnagiri & Tamil Nadu & GPU28 \\
\hline $\mathbf{6}$ & TNNB6 & Krishnagiri & Tamil Nadu & Neck \\
\hline $\mathbf{7}$ & TNNB7 & Dharmapuri & Tamil Nadu & Neck & GPU28 \\
\hline $\mathbf{8}$ & TNNB8 & Coimbatore & Tamil Nadu & Leaf & RAU252 \\
\hline $\mathbf{9}$ & JALB9 & Ranchi & Jharkhand & Neck & RAUf \\
\hline $\mathbf{1 0}$ & JANB10 & Ranchi & Jharkhand & Neck & PR202 \\
\hline $\mathbf{1 2}$ & BILB11 & Dholi & Bihar & Finger & Neck \\
\hline $\mathbf{1 3}$ & BINB12 & Dholi & Bihar & PR202 \\
\hline $\mathbf{1 4}$ & BIFB13 & Dholi & Bihar & Neck & GR 708 \\
\hline $\mathbf{1 5}$ & MANB14 & Vizianagaram & Andhra Pradesh & Neck & KM252 \\
\hline $\mathbf{1 6}$ & ODNB16 & Dindori & Madhya Pradesh & Neck & KM252 \\
\hline $\mathbf{1 7}$ & ODNB17 & Berhampur & Odisha & Neck & Local \\
\hline $\mathbf{1 8}$ & JANB18 & Sisai & Odisha & Neck & Local \\
\hline $\mathbf{1 9}$ & JANB19 & Sisai & Jharkhand & Finger & Local \\
\hline $\mathbf{2 0}$ & JAFB20 & Sisai & Jharkhand & Leaf & Local \\
\hline $\mathbf{2 1}$ & MALB21 & Rewa & Jharkhand & Leaf & Local \\
\hline $\mathbf{2 2}$ & MALB22 & Rewa & Madhya Pradesh & Madhya Pradesh & Local \\
\hline $\mathbf{2 4}$ & MANB23 & Rewa & Madhya Pradesh & GPU64 \\
\hline
\end{tabular}

Table.2 Pathogenicity potential of $M$. grisea isolates of finger millet

\begin{tabular}{|c|c|c|}
\hline S. NO. & Isolates & Leaf blast (1-9 scale** \\
\hline $\mathbf{1}$ & TNLB1 & 8.76 \\
\hline $\mathbf{2}$ & TNLB2 & 6.55 \\
\hline $\mathbf{4}$ & TNLB3 & 6.24 \\
\hline $\mathbf{5}$ & TNLB4 & 7.17 \\
\hline $\mathbf{6}$ & TNNB5 & 4.87 \\
\hline $\mathbf{7}$ & TNNB6 & 6.13 \\
\hline $\mathbf{8}$ & TNNB7 & 8.02 \\
\hline $\mathbf{9}$ & TNNB8 & 8.68 \\
\hline $\mathbf{1 1}$ & JALB9 & 8.12 \\
\hline $\mathbf{1 2}$ & JANB10 & 6.79 \\
\hline $\mathbf{1 3}$ & BILB11 & 7.50 \\
\hline $\mathbf{1 4}$ & BINB12 & 5.43 \\
\hline $\mathbf{1 5}$ & BIFB13 & 8.41 \\
\hline $\mathbf{1 7}$ & ANNB14 & 6.12 \\
\hline $\mathbf{1 8}$ & MANB15 & 7.83 \\
\hline $\mathbf{1 9}$ & ODNB16 & 7.82 \\
\hline $\mathbf{2 0}$ & ODNB17 & 4.77 \\
\hline $\mathbf{2 1}$ & JANB18 & 8.16 \\
\hline $\mathbf{2 3}$ & JANB19 & 5.40 \\
\hline $\mathbf{2 4}$ & JAFB20 & 7.65 \\
\hline $\mathbf{4 n}$ & MALB21 & 6.00 \\
\hline
\end{tabular}

*Mean of three replication 
Table.3 Colony characters of $M$. grisea isolates on different solid media

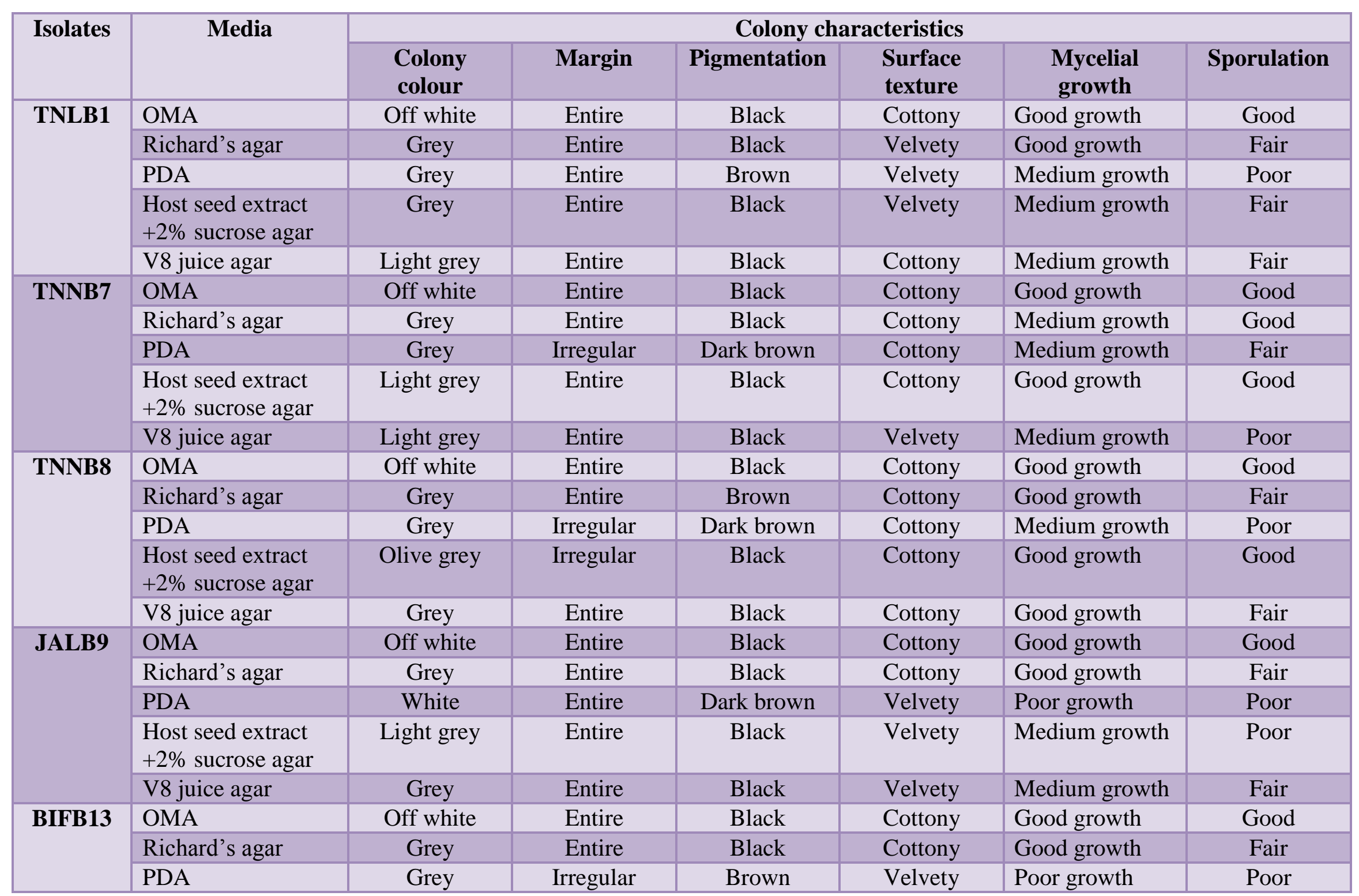




\begin{tabular}{|c|c|c|c|c|c|c|c|}
\hline & $\begin{array}{l}\text { Host seed extract } \\
+2 \% \text { sucrose agar }\end{array}$ & Olive grey & Entire & Black & Velvety & Medium growth & poor \\
\hline & V8 juice agar & Grey & Entire & Black & Cottony & Medium growth & Poor \\
\hline \multirow{3}{*}{ JANB18 } & OMA & Light grey & entire & Black & Cottony & Good growth & Good \\
\hline & PDA & Grey & Entre & Dark brown & Cottony & Medium growth & Poor \\
\hline & $\begin{array}{l}\text { Host seed extract } \\
+2 \% \text { sucrose agar }\end{array}$ & Olive grey & Entire & Black & Cottony & Good growth & Fair \\
\hline \multirow[t]{5}{*}{ MANB23 } & OMA & white & Entire & Black & Cottony & Good growth & Good \\
\hline & Richard's agar & Grey & Entire & Black & Cottony & Good growth & Fair \\
\hline & PDA & Grey & Irregular & Dark brown & Cottony & Medium growth & Poor \\
\hline & $\begin{array}{l}\text { Host seed extract } \\
+2 \% \text { sucrose agar }\end{array}$ & Olive grey & Entire & Black & Cottony & Good growth & Fair \\
\hline & V8 juice agar & Light grey & Entire & Black & Cottony & Medium growth & Poor \\
\hline
\end{tabular}

Table.4 Effect of different solid media on the mycelial growth of M. grisea isolates

\begin{tabular}{|c|c|c|c|c|c|}
\hline \multirow[t]{2}{*}{ Isolates } & \multicolumn{5}{|c|}{ Colony diameter $(\mathrm{mm})$} \\
\hline & Oat Meal Agar & Richards's Agar & Potato Dextrose Agar & $\begin{array}{l}\text { Host seed extract }+2 \% \\
\text { sucrose Agar }\end{array}$ & V8 juice Agar \\
\hline TNLB1 & $85.00^{\mathrm{a}}$ & $80.20^{\mathrm{a}}$ & $82.60^{\mathrm{a}}$ & $81.20^{\mathrm{ab}}$ & $84.30^{\mathrm{a}}$ \\
\hline TNNB7 & $76.10^{b c}$ & $70.80^{b c}$ & $70.80^{b}$ & $73.40^{c}$ & $68.00^{b}$ \\
\hline TNNB8 & $86.00 \mathrm{a}$ & $81.80^{\mathrm{a}}$ & $81.70^{\mathrm{a}}$ & $84.20^{\mathrm{a}}$ & $77.60^{\mathrm{a}}$ \\
\hline JALB9 & $83.00^{\mathrm{ab}}$ & $78.00^{\mathrm{ab}}$ & $81.00^{\mathrm{a}}$ & $81.80^{\mathrm{ab}}$ & $84.20^{\mathrm{a}}$ \\
\hline BIFB13 & $79.20^{\mathrm{abc}}$ & $75.00^{\mathrm{ab}}$ & $65.40^{\mathrm{bc}}$ & $67.40^{\mathrm{c}}$ & $66.40^{\mathrm{b}}$ \\
\hline JANB18 & $79.00^{\mathrm{abc}}$ & $67.20^{c}$ & $62.20^{c}$ & $75.00^{\mathrm{bc}}$ & $78.00^{\mathrm{a}}$ \\
\hline MANB23 & $72.60^{c}$ & $79.80^{\mathrm{a}}$ & $64.00^{\mathrm{bc}}$ & $68.10^{c}$ & $67.20^{b}$ \\
\hline Mean & 80.12 & 76.11 & 72.52 & 75.87 & 75.10 \\
\hline
\end{tabular}

In a column, means followed by the same letter ( $\mathrm{s})$ are not statistically different $(\mathrm{p}=0.05)$ by DMRT 
Table.5 Conidial characteristics of $M$. grisea isolates

\begin{tabular}{|c|c|c|c|c|c|c|c|}
\hline \multirow[t]{4}{*}{ Isolates } & \multicolumn{7}{|c|}{ Conidial characteristics } \\
\hline & \multicolumn{4}{|c|}{ Conidial size $(\mu \mathrm{m})$} & \multirow{3}{*}{$\begin{array}{l}\text { Conidial } \\
\text { shape }\end{array}$} & \multirow[t]{3}{*}{ Conidial colour } & \multirow{3}{*}{$\begin{array}{l}\text { Sporulation } \\
\left(\times 10^{-5}\right. \\
\left.\text { conidia } \mathrm{ml}^{-1}\right)\end{array}$} \\
\hline & \multicolumn{2}{|c|}{ Length } & \multicolumn{2}{|c|}{ Width } & & & \\
\hline & Range & Mean & Range & Mean & & & \\
\hline TNLB1 & $18.77-21.75$ & 19.45 & $7.45-7.82$ & 7.60 & Pyriform & hyaline to pale olive & 6 \\
\hline TNNB7 & $17.07-20.18$ & 17.82 & $6.86-5.80$ & 6.25 & Pyriform & hyaline to pale olive & 2 \\
\hline TNNB8 & $21.52-23.66$ & 21.91 & $7.82-7.03$ & 7.42 & Pyriform & hyaline to pale olive & 4 \\
\hline JALB9 & $16.00-18.23$ & 16.54 & $5.68-4.97$ & 5.29 & Pyriform & hyaline to pale olive & 3 \\
\hline BIFB13 & $16.21-21.02$ & 17.88 & $6.13-5.78$ & 5.92 & Pyriform & hyaline to pale olive & 4 \\
\hline JANB18 & $17.32-20.19$ & 18.32 & $6.73-6.32$ & 6.49 & Pyriform & hyaline to pale olive & 2 \\
\hline MANB23 & $15.98-18.78$ & 16.65 & $5.37-5.00$ & 5.16 & Pyriform & hyaline to pale olive & 1 \\
\hline
\end{tabular}

Table.6 Influence of temperature on the radial growth of $M$. grisea isolates

\begin{tabular}{|c|c|c|c|c|c|}
\hline \multirow[t]{2}{*}{ Isolates } & \multicolumn{5}{|c|}{ Radial growth $(\mathrm{mm})$ at different temperature* } \\
\hline & $15^{0} \mathrm{C}$ & $20^{0} \mathrm{C}$ & $25^{0} \mathrm{C}$ & $30{ }^{0} \mathrm{C}$ & $35^{0} \mathrm{C}$ \\
\hline TNLB1 & $14.90^{\mathrm{a}}$ & $51.60^{b}$ & $78.90^{\mathrm{a}}$ & $64.10^{\mathrm{abc}}$ & $9.20^{\mathrm{a}}$ \\
\hline TNNB7 & $13.50^{b}$ & $43.80^{c}$ & $72.40^{\mathrm{ab}}$ & $68.40^{\mathrm{ab}}$ & $3.80^{\mathrm{cd}}$ \\
\hline TNNB8 & $15.70^{\mathrm{a}}$ & $56.10^{\mathrm{a}}$ & $73.70^{\mathrm{ab}}$ & $61.30^{c}$ & $4.10^{c}$ \\
\hline JALB9 & $15.20^{\mathrm{a}}$ & $59.30^{\mathrm{a}}$ & $77.80^{\mathrm{a}}$ & $70.10^{\mathrm{a}}$ & $6.00^{\mathrm{b}}$ \\
\hline BIFB13 & $13.20^{b}$ & $40.20^{c}$ & $75.40^{\mathrm{ab}}$ & $63.20^{b c}$ & $3.40^{\mathrm{de}}$ \\
\hline JANB18 & $12.80^{b}$ & $50.40^{b}$ & $70.30^{b}$ & $65.80^{\mathrm{abc}}$ & $3.00^{\mathrm{e}}$ \\
\hline MANB23 & $13.10^{b}$ & $43.60^{c}$ & $74.60^{\mathrm{ab}}$ & $60.30^{c}$ & $2.30^{f}$ \\
\hline Mean & 14.05 & 49.28 & 74.73 & 64.74 & 4.54 \\
\hline
\end{tabular}

*Mean of three replications

In a column, means followed by the same letter ( $\mathrm{s}$ ) are not statistically different $(\mathrm{p}=0.05)$ by DMRT 
Table.7 Influence of temperature on the sporulation of $M$. grisea isolates

\begin{tabular}{|c|c|c|c|c|c|}
\hline \multirow[t]{2}{*}{ Isolates } & \multicolumn{5}{|c|}{ Sporulation $\left(\mathrm{x}^{-5} 0^{-5}\right.$ conidia $\left.\mathrm{ml}^{-1}\right)$ at different temperature* } \\
\hline & $15^{0} \mathrm{C}$ & $20{ }^{\circ} \mathrm{C}$ & $25^{\circ} \mathrm{C}$ & $30{ }^{\circ} \mathrm{C}$ & $35^{0} \mathrm{C}$ \\
\hline TNLB1 & 0.0 & $1.8^{\mathrm{a}}$ & $3.6^{\mathrm{a}}$ & $2.3^{\mathrm{a}}$ & 0.0 \\
\hline TNNB7 & 0.0 & $0.7^{\mathrm{d}}$ & $1.8^{\mathrm{c}}$ & $1.3^{\mathrm{d}}$ & 0.0 \\
\hline TNNB8 & 0.0 & $1.6^{\mathrm{b}}$ & $2.2^{b}$ & $1.2^{\mathrm{d}}$ & 0.0 \\
\hline JALB9 & 0.0 & $1.8^{\mathrm{a}}$ & $2.4^{b}$ & $2.1^{b}$ & 0.0 \\
\hline BIFB13 & 0.0 & $1.5^{\mathrm{b}}$ & $1.9^{c}$ & $2.0^{\mathrm{b}}$ & 0.0 \\
\hline JANB18 & 0.0 & $1.4^{\mathrm{bc}}$ & $2.1^{\mathrm{bc}}$ & $1.7^{\mathrm{c}}$ & 0.0 \\
\hline MANB23 & 0.0 & $1.2^{\mathrm{c}}$ & $1.6^{\mathrm{d}}$ & $1.6^{\mathrm{c}}$ & 0.0 \\
\hline Mean & 0.0 & 1.4 & 2.2 & 1.7 & 0.0 \\
\hline
\end{tabular}

*Mean of three replications

In a column, means followed by the same letter $(s)$ are not statistically different $(p=0.05)$ by DMRT

Table.8 Influence of $\mathrm{pH}$ level on the dry mycelial weight of $M$. grisea isolates

\begin{tabular}{|c|c|c|c|c|c|c|c|c|c|c|}
\hline \multirow[t]{2}{*}{ Isolates } & \multicolumn{10}{|c|}{ Dry mycelial weight (mg) at different pH Level* } \\
\hline & 3.0 & 3.5 & 4.0 & 4.5 & 5.0 & 5.5 & 6.0 & 6.5 & 7.0 & 7.5 \\
\hline TNLB1 & $10.26^{\mathrm{a}}$ & $22.12^{\mathrm{c}}$ & $53.38^{\mathrm{b}}$ & $70.70^{b}$ & $99.20^{\mathrm{a}}$ & $102.33^{b}$ & $164.56^{\mathrm{a}}$ & $230.45^{\mathrm{a}}$ & $146.40^{\mathrm{a}}$ & $101.67^{\mathrm{ab}}$ \\
\hline TNNB8 & $3.73^{\mathrm{e}}$ & $22.21^{\mathrm{c}}$ & $22.98^{\mathrm{d}}$ & $71.95^{b}$ & $94.93^{\mathrm{a}}$ & $106.88^{\mathrm{ab}}$ & $150.53^{\mathrm{ab}}$ & $222.88^{b c}$ & $129.63^{d}$ & $94.19^{\mathrm{bc}}$ \\
\hline JALB9 & $10.31^{\mathrm{a}}$ & $39.72^{b}$ & $50.80^{b c}$ & $72.21^{b}$ & $84.99^{b c}$ & $102.97^{b}$ & $167.43^{\mathrm{a}}$ & $219.67^{c}$ & $146.40^{\mathrm{a}}$ & $105.67^{a}$ \\
\hline MANB23 & $4.56^{\mathrm{d}}$ & $10.33^{\mathrm{e}}$ & $26.24^{d}$ & $51.47^{c}$ & $77.79^{c}$ & $109.10^{\mathrm{ab}}$ & $160.34^{\mathrm{ab}}$ & $211.08^{f}$ & $118.65^{\mathrm{f}}$ & $87.50^{c}$ \\
\hline Mean & 7.26 & 23.66 & 41.69 & 71.92 & 90.13 & 105.61 & 156.98 & $216 . .54$ & 141.77 & 87.46 \\
\hline
\end{tabular}

*Mean of three replications

In a column, means followed by the same letter ( $)$ are not statistically different $(p=0.05)$ by DMRT 
Table.9 Effect of different carbon sources on the mycelial growth of $M$. grisea isolates

\begin{tabular}{|c|c|c|c|c|c|c|c|}
\hline S. No. & \multirow{2}{*}{ Isolates } & \multicolumn{7}{|c|}{ Colony diameter (mm)* } \\
\cline { 3 - 8 } & & Dextrose & Maltose & D- fructose & Sucrose & Glucose & Galactose \\
\hline $\mathbf{1}$ & TNLB1 & $88.60^{\mathrm{a}}$ & $82.60^{\mathrm{ab}}$ & $84.00^{\mathrm{a}}$ & $81.70^{\mathrm{a}}$ & $84.50^{\mathrm{a}}$ & $79.30^{\mathrm{a}}$ \\
\hline $\mathbf{2}$ & TNNB7 & $81.60^{\mathrm{ab}}$ & $86.30^{\mathrm{a}}$ & $74.50^{\mathrm{bc}}$ & $70.50^{\mathrm{c}}$ & $79.40^{\mathrm{ab}}$ & $84.80^{\mathrm{a}}$ \\
\hline $\mathbf{3}$ & TNNB8 & $84.20^{\mathrm{ab}}$ & $78.20^{\mathrm{b}}$ & $68.90^{\mathrm{c}}$ & $74.50^{\mathrm{bc}}$ & $80.20^{\mathrm{ab}}$ & $71.80^{\mathrm{b}}$ \\
\hline $\mathbf{4}$ & JALB9 $^{\mathrm{b}}$ & $83.90^{\mathrm{ab}}$ & $82.10^{\mathrm{ab}}$ & $80.10^{\mathrm{ab}}$ & $78.20^{\mathrm{ab}}$ & $82.00^{\mathrm{ab}}$ & $78.90^{\mathrm{a}}$ \\
\hline $\mathbf{5}$ & BIFB13 & $80.10^{\mathrm{b}}$ & $79.50^{\mathrm{ab}}$ & $78.70^{\mathrm{ab}}$ & $70.10^{\mathrm{c}}$ & $74.70^{\mathrm{b}}$ & $69.00^{\mathrm{b}}$ \\
\hline $\mathbf{6}$ & JANB18 & $85.20^{\mathrm{ab}}$ & $82.10^{\mathrm{ab}}$ & $80.10^{\mathrm{ab}}$ & $70.90^{\mathrm{c}}$ & $84.20^{\mathrm{a}}$ & $81.70^{\mathrm{a}}$ \\
\hline $\mathbf{7}$ & MANB23 & $82.60^{\mathrm{ab}}$ & $80.20^{\mathrm{ab}}$ & $78.40^{\mathrm{ab}}$ & $80.60^{\mathrm{ab}}$ & $80.90^{\mathrm{ab}}$ & $80.00^{\mathrm{a}}$ \\
\hline & Mean & $\mathbf{8 3 . 7 4}$ & $\mathbf{8 1 . 5 7}$ & $\mathbf{7 7 . 8 1}$ & $\mathbf{7 5 . 2 1}^{\mathrm{ab}}$ & $\mathbf{8 0 . 8 4}$ & $\mathbf{7 7 . 9 3}$ \\
\hline
\end{tabular}

*Mean of three replications

In a column, means followed by the same letter ( $\mathrm{s})$ are not statistically different $(\mathrm{p}=0.05)$ by DMRT

Table.10 Effect of different nitrogen sources on the mycelial growth of $M$. grisea isolates

\begin{tabular}{|c|c|c|c|c|c|c|c|}
\hline \multirow[t]{2}{*}{ S. No. } & \multirow[t]{2}{*}{ Isolates } & \multicolumn{6}{|c|}{ Colony diameter $(\mathrm{mm}) *$} \\
\hline & & L-glycine & $\mathrm{KNO}_{3}$ & L - arginine & $\mathrm{NaNO}_{3}$ & Asparagine & Peptone \\
\hline 1 & TNLB1 & $86.70^{\mathrm{a}}$ & $85.20^{\mathrm{ab}}$ & $87.90^{\mathrm{a}}$ & $88.40^{\mathrm{a}}$ & $76.50^{\mathrm{ab}}$ & $81.40^{\mathrm{a}}$ \\
\hline 2 & TNNB7 & $74.10^{c}$ & $80.10^{\mathrm{abc}}$ & $76.30^{b}$ & $81.30^{\mathrm{a}}$ & $82.10^{\mathrm{a}}$ & $76.10^{\mathrm{a}}$ \\
\hline 3 & TNNB8 & $80.90^{\mathrm{abc}}$ & $78.20^{\mathrm{bc}}$ & $77.60^{b}$ & $85.60^{\mathrm{a}}$ & $82.80^{\mathrm{a}}$ & $79.30^{\mathrm{a}}$ \\
\hline 4 & JALB9 & $84.30^{\mathrm{ab}}$ & $87.10^{\mathrm{a}}$ & $88.20^{\mathrm{a}}$ & $87.90^{\mathrm{a}}$ & $70.40^{b}$ & $79.40^{\mathrm{a}}$ \\
\hline 5 & BIFB13 & $78.40^{\mathrm{bc}}$ & $73.20^{c}$ & $75.20^{b}$ & $87.00^{\mathrm{a}}$ & $76.30^{\mathrm{ab}}$ & $83.10^{\mathrm{a}}$ \\
\hline 6 & JANB18 & $80.50^{\mathrm{abc}}$ & $78.30^{\mathrm{bc}}$ & $81.10^{\mathrm{ab}}$ & $86.50^{\mathrm{a}}$ & $77.80^{\mathrm{a}}$ & $76.30^{\mathrm{a}}$ \\
\hline 7 & MANB23 & $81.10 \mathrm{a}^{\mathrm{bc}}$ & $74.10^{c}$ & $82.30 \mathrm{ab}$ & $84.40^{\mathrm{a}}$ & $80.30^{\mathrm{a}}$ & $79.73^{\mathrm{a}}$ \\
\hline \multicolumn{2}{|c|}{ Mean } & 80.86 & 79.45 & 81.23 & 85.87 & 78.03 & 79.33 \\
\hline
\end{tabular}

*Mean of three replications

In a column, means followed by the same letter ( $s)$ are not statistically different $(\mathrm{p}=0.05)$ by DMRT

Mijan Hossain (2000) who observed that the mycelium in cultures was first hyaline in colour then changed to olivaceous, $1-5.2 \mu \mathrm{m}$ in width, septate and branched. The aerial mycelium was white to grey, as it was observed by Getachew et al., (2013). Getachew et al., (2014) reported that the shape of the conidia was typically pyriform with rounded base, apex narrowed, 2-3 septate, 2-4 celled and middle cells were swollen. Recently, Asfaha et al., (2015) showed that $P$. grisea conidia was pyriform in shape, base rounded, apex narrowed, two septate with three celled, hyaline to pale olive colors.

\section{Physiological studies}

Influence of temperature on the mycelial growth and sporulation of $M$. grisea

Temperature is one of the most important physical environmental factors for regulating the growth and reproduction of $M$. grisea isolates. All the isolates showed different responses to the different incubation temperatures (Table 6). There was maximum mean radial mycelial growth occurred at 25 ${ }^{0} \mathrm{C}$ and $30{ }^{0} \mathrm{C}$ with $74.73 \mathrm{~mm}$ and $64.74 \mathrm{~mm}$ respectively. The lesser mean radial mycelial growth at 15, 20 and $35{ }^{\circ} \mathrm{C}$ with $14.05,49.28$ 
and $4.54 \mathrm{~mm}$. However the temperature $25{ }^{\circ} \mathrm{C}$ was found optimum for the growth of all the isolates. All the isolates produced the maximum mean sporulation at 20,25 and 30 ${ }^{0} \mathrm{C}$ with $1.4,2.2$ and $1.7 \times 10^{+5}$ conidia $\mathrm{ml}^{-1}$ respectively, but did not sporulate at 15 and $35{ }^{0} \mathrm{C}$ (Table 7). Among the isolates of $M$. grisea at temperature $25{ }^{0} \mathrm{C}$, maximum sporulation was recorded in TNLB1, JALB9, TNNB8 and JANB18 with 3.6, 2.4, 2.2 and $2.1 \times 10^{+5}$ conidia $\mathrm{ml}^{-1}$ respectively. This is in agreement with the earlier work of Arunkumar and Singh (1995) who studied the differential response of $P$. grisea isolates from rice, finger millet and pear millet to temperature and reported that the maximum growth at $30^{\circ} \mathrm{C}$. The results of the present study was in corroboration with Netam et al., (2013); Getachew et al., 2013; 2014 have recorded the highest mycelium growth and sporulation of $P$. grisea isolate of finger millet at $25-30^{\circ} \mathrm{C}$. The most suitable temperature for mycelial growth was observed as $25^{\circ} \mathrm{C}$ which was reported by Fu et al., (2013); Asfaha et al., (2015) and the similar result was also obtained in the present result.

Influence of pH level on the dry mycelial weight of $M$. grisea

The results on the effect of different $\mathrm{pH}$ level on the growth of $M$. grisea isolates in Richard's medium revealed that, the optimum $\mathrm{pH}$ for the growth was found to be $\mathrm{pH} 6.5$ with maximum mean dry mycelial weight of $216.54 \mathrm{mg}$ followed by $\mathrm{pH} 6.0(156.98 \mathrm{mg})$ and $7.0(141.77 \mathrm{mg})$. The $\mathrm{pH}$ of 7.5, 5.5, 5.0, 4.54.0, 3.5 and 3.0 recorded less mean mycelial dry weight of $87.46,105.61,90.13$, $71.92,41.69,23.66$ and $7.26 \mathrm{mg}$, respectively (Table 8). This is in concordance with the finding of Arunkumar and Singh (1995) who opined the best growth at $\mathrm{pH} 6.5$ for the $P$. grisea isolates. Similar result was also reported by Mijan Hossain (2000) who highlighted that the growth of $P$. grisea isolates increased with increase in $\mathrm{pH}$ from 3.5 to 6.5. The result was in accordance with Meena (2005) who reported that the $\mathrm{pH} 6.5$ was significantly superior for the growth $P$. grisea over other treatments. The findings of the present study was also in accordance with Getachew et al., (2014) and Asfaha et al., (2015) stated that the maximum mycelial growth of $P$. grisea was recorded at $\mathrm{pH} 6.5$ followed by $\mathrm{pH} 6.0$ and $\mathrm{pH}$ 7.0.

\section{Biochemical studies}

\section{Effect of different carbon sources on the mycelial growth of $M$. grisea}

The results revealed that the different carbon sources supplemented in the growing medium showed significant difference in utilization of carbon sources by different isolates of $M$. grisea (Table 9). Among the carbon sources, dextrose was found to be the best carbon source by recording the highest mean mycelial growth of $83.74 \mathrm{~mm}$ followed by maltose, glucose, galactose, D - fructose and sucrose with mean mycelial growth of 81.57 , 80.84, 77.93, 77.81 and $75.21 \mathrm{~mm}$, respectively. In dextrose, maximum mycelial growth was noticed in the isolate TNLB1 with $88.60 \mathrm{~mm}$ followed by JANB18 with 85.20 $\mathrm{mm}$. In maltose, maximum mycelial growth was observed in the isolate TNNB7 with $86.30 \mathrm{~mm}$. In glucose, maximum mycelial growth was observed in isolate TNLB1 with $84.50 \mathrm{~mm}$.

In galactose, maximum mycelial growth was observed in isolate TNNB7 with $84.80 \mathrm{~mm}$. In D - fructose, TNLB1 recorded the maximum mycelial growth of $84.00 \mathrm{~mm}$. In sucrose as carbon source, the isolate TNLB1 recorded the maximum mycelial growth of $81.70 \mathrm{~mm}$. This is in corroboration with a result of Gatachew at el. (2014) who reported that dextrose as a good carbon sources for 
higher mean colony diameter. Hossain (2004) noted considerable variation in the ability to use various carbon sources thereby indicating biochemical differences among the $P$. grisea isolates. Tripathi (2006) has also reported that maltose better used as the carbon source for the mycelial growth and sporulation.

Whereas the fungal pathogen $P$. grisea on pearl millet showed maximum mycelial growth in starch supplemented media followed by sucrose (Mijan Hossain, 2000). Netam et al., (2013) have indicated that among the different carbon sources, glucose supported significantly higher mycelial growth of $M$. grisea followed by sucrose, galactose.

\section{Effect of different nitrogen sources on the mycelial growth of $M$. grisea isolates}

Results showed that, variable utilization nitrogen sources viz., L- glycine, $\mathrm{KNO}_{3}$, Larginine, $\mathrm{NaNO}_{3}$, asparagine and peptone by each $M$. grisea isolate. Maximum growth was observed in $\mathrm{NaNO}_{3}$ with maximum mean mycelial growth of $85.87 \mathrm{~mm}$ followed by $\mathrm{L}$ arginine, $\mathrm{L}$ - glycine, $\mathrm{KNO}_{3}$, peptone and asparagine with radial mycelial growth of $81.23,80.86,79.45,79.33$ and $78.03 \mathrm{~mm}$ respectively.

In $\mathrm{NaNO}_{3}$, maximum growth was noticed in the isolates viz., TNLB1, JALB9 and BIFB13 with $88.40,87.90$ and $87.00 \mathrm{~mm}$ respectively, while in L - arginine the isolate JALB9 recorded the maximum mycelial growth of $88.20 \mathrm{~mm}$. In L - glycine, the isolate TNLB1 recorded the maximum mycelial growth of $86.70 \mathrm{~mm}$.

In $\mathrm{KNO}_{3}$, the isolate JALB9 recorded the maximum mycelial growth of $87.10 \mathrm{~mm}$. In peptone, the isolate BIFB13 recorded the maximum mycelial growth of $83.10 \mathrm{~mm}$. In asparagine supplemented medium, the isolates viz., TNNB8 and TNNB7 recorded the maximum mycelial growth of 82.80 and $82.10 \mathrm{~mm}$ respectively (Table 10). Earlier work of Mijan Hossain (2000) enunciated that the asparagine was the best nitrogen source for the growth of $M$. grisea which was significantly superior from other nitrogen sources studied in that study. Gatachew at el. (2014) reported that NaNO3 were the most suitable nitrogen sources for mycelial growth of P. grisea. Netam et al., (2013) have supported that nitrogen source such as ammonium nitrates favoured the mycelial growth and sporulation of $P$. grisea. Anil Kumar (2015) also reported that among nitrogen sources, Colletotrichum capsici preferred potassium nitrate followed by sodium nitrate and asparagines.

The study clearly indicated that the response by $M$. grisea isolates to exogenous supply of nitrogenous compounds was variable among the isolates.

From this study it is clear that the Oat Meal Agar medium (OMA) was found best for the growth of $M$. grisea isolates tested. The temperature $25^{\circ} \mathrm{C}$ and $\mathrm{pH} 6.5$ was found to be ideal for growth, sporulation and mycelial dry weight of $M$. grisea isolates.

Richard's medium with supplemented carbon and nitrogen sources viz., dextrose and NaNo3 supported the maximum mean mycelial growth of $M$. grisea isolates of finger millet.

\section{Acknowledgement}

Authors have acknowledged UGC for providing Rajiv Gandhi National Fellowship, Government of India to carry out this research and technically facilitated by All India Coordinated Small Millet Improvement Project Centre (AICSMIP), Coimbatore centre. 


\section{References}

Afshana, B.D., Shahijahan, M., Hussain, D.S. and Snober, H.B. 2011. Morphological variability among various isolates of Magnaporthe grisea collected from paddy growing areas of Kashmir. Int. J. Pharm. Sci. Rev. Res., 8(1): 45-56.

Anil Kumar, K. 2015. Studies of different carbon and nitrogen sources on the growth of Colletotrichum capsici, the causal organism of Anthracnose of Chilli. Int. J. Appl. Res., 1(4): 38-39.

Arunkumar and Singh, R.A. 1995. Differential response of Pyricularia grisea isolates from rice, finger millet and pearl millet to media, temperature, $\mathrm{pH}$ and light. Indian J. Mycol. Plant Pathol., 25: 238 - 242.

Asfaha, M. G., Selvaraj, T. and Woldeab, G. 2015. Assessment of disease intensity and isolates characterization of blast disease (Pyricularia oryzae cav.) from South West of Ethiopia. -Int. J. Life Sci., 3(4): 271286.

Dida, M.M., Wanyera, N., Dunn, L.H., Bennetzen, J.L. and Devos, K.M. (008. Population structure and diversity in finger millet (Eleusine coracana) Germplasm. Trop. Plant Biol., 1: 131-141.

Fu, R., Yin, C., Liu, Y., Ding, L., Zhu, J., Zheng, A. and Li, P. 2013. The influence of nutrient and environmental factors on mycelium growth and conidium of false smut Villosiclava virens. Afr. J. Microbiol. Res., 7: 825-833.

Getachew, G., Tesfaye, A. and Kassahun, T. 2013. Evaluation of disease incidence and severity and yield loss of finger millet variety and mycelial growth inhibition of Pyricularia grisea isolates using biological antagonists and fungicide in vitro condition. J. Appl. Biosci., 73: 58835901.

Getachew, G., Tesfaye. A. and Kassahun, T. 2014. Morphological, physiology and biochemical studies on Pyricularia grisea isolates causing blast disease on finger millet, Ethiopia. J. Appl. Biosci., 74: 6059-6071.
Gomez, K.A. and Gomez, A.A. 1984. Statistical Procedure for Agricultural Research. John Wiley and Sons, New York.

Hall, I. M. and Bell, I. V. 1961. Further studies on the effect of temperature on the growth of some entomophthoraceous fungi. $J$. Invertebr. Pathol., 3: 289-296.

Hossain, M.M., Srikant, K. and Hegde, Y.R. 2004. Physiological and nutritional studies on Pyricularia grisea, the causal agent of blast of rice. Karnataka J. Agric. Sci., 17(4): 851-853.

Khadka, R.B., Shrestha, S.M., Manandhar, H.K. and Gopal, B.K.C. 2012. Study on differential response of Pyricularia grisea isolates from rice, finger millet and Panicum sp. with local and alien media and their host range. NJST., 13(2): 7-14.

Kumar, A. and Singh, R.A. 1995. Differential response of Pyricularia grisea isolates from rice, finger millet and pearl millet to media, temperature, $\mathrm{pH}$ and light. Indian J. Mycol. Plant Pathol., 25(3): 238-242.

Latha, A.M., Rao, K.V and Reddy, V.D. 2005. Production of transgenic plants resistant to leaf blast disease in finger millet (Eleusine coracana (L.) Gaertn.). Plant Sci., 169(4): 657-667.

Mackill, D. J. and Bonman, J. M. 1992. Inheritance of blast resistance in nearisogenic lines of rice. Phytopathology, 82: 746-749.

Maharaja, 2012. Studies on molecular variability and cross infectivity of blast pathogen (Magnaporthe grisea) (Hebert) Barr in finger millet, M.Sc. (agri) thesis Tamil Nadu Agricultural University, Coimbatore, India.

Meena, B.S. 2005. Morphological and molecular variability of rice blast pathogen, Pyricularia grisea (Cooke) Sacc. Department of Plant Pathology, College of Agriculture, Dharwad University of Agricultural Sciences, Dharwad. Pp. 12-54.

Mijan Hossain, M.D. (2000). Studies on blast disease of rice caused by Pyricularia grisea (Cooke) Sacc. in upland areas. M.Sc. Thesis, University of Agricultural 
Sciences, Dharwad, Pp. $52-53$.

Nagaraja, A. and Mantur, S.G. 2007. Screening of Eleusine coracana germplasm for blast resistance. J. Mycopathol. Res., 45(1): 6668.

Nagendran, K. 2011. Exploitation of endophytes for the management of major diseases of rice. M.Sc. (Ag.,) Thesis, Tamil Nadu Agricultural University, Coimbatore, India. p. 222.

Netam, R.S., Bahadur, A.N., Tiwari, R.K.S. and Tiwari, U. 2013. Effect of different culture media, carbon source, nitrogen source, temperature and $\mathrm{pH}$ level on the growth and sporulation of Pyricularia grisea isolate from finger millet. Res. $J$. agric. Sci., 4(1): 83-86.

Otsuka, H., Tamari, K. and Agaraswara, N. 1957. Biochemical classification of Pyricularia oryzae cav. (1-4). J. Agric. Chem. Soc. Jpn., 31: $791-798$.

Ou, S. H. 1985. Rice Diseases. Commonwealth Mycological Institute, Kew, Surrey, England.

Ruiz, C.P. 2003. A new means of control for Pyricularia oryzae, Rhizoctonia solani and other important rice-disease pathogens in Colombia. Pfl AnzenschutzNachrichten Bayer, 56: 399-416.

Shanmugapackiam, S., Parthasarathy, S., Nakkeeran, S. and Raguchander, T. 2017. Detection of finger millet blast pathogen Magnaporthe grisea using FTIR spectroscopy. Chem. Sci. Rev. Lett., 6(22): 956-960.

Srinivasachary, Hittalmani, S., Shivayogi, S.,
Vaishali, M.G., Shashidhar, H.E. and Girishkumar, K. 2002. Genetic analysis of rice blast fungus of southern Karnataka using DNA markers and reaction of popular rice genotypes. Curr. Sci., 82: 732-735.

Susan, P.M. and Ambika, C. 2011. Culture media influence on vegetative growth and in vitro conidia production of Magnaporthe oryzae. Cell and Plant Sci., 2 (3): 9-11.

Tripathi, S.K. 2006. Effect of media, pH, nitrogen, carbon sources and light on the growth and sporulation of Pyricularia grisea. Ann. Plant Protect. Sci., 14(1): 166-168.

Tuite, J. 1969. Plant pathological methods, fungi and bacteria. Burges Publishing Company, USA, p. 239.

Uddin, W. 2000. Gray leaf spot comes on strong. [Online] available: http://groundsmag.Com/ar/grounds maintenance_gray_leaf_spot/ (09 Oct. 2008).

Upadhyaya, H.D., Pundir, R.P.S and Gowda, C.L.L. 2007. Genetic resources diversity of finger millet - A global perspective. In: Finger millet blast management in East Africa. Creating opportunities for improving production and utilization of finger millet. (Eds. Mgonja, M.A., Lenne, J.M., Manyasa, E. and Sreenivasaprasad, S.), International Crops Research Institute for the Semi-Arid Tropics, Patancheru, Andhra Pradesh, India. 90: 978-992.

Vogel, A. I., 1951. A text book in organic quantitative analysis, congmcans. Green and co., London, N. Y., Toronto, Pp. 865 -872 .

\section{How to cite this article:}

Shanmugapackiam, S., S. Irulandi, P. Murali Sankar, A. Nagaraja and Raguchander, T. 2019. Cultural, Morphological, Physiological and Biochemical Characteristics of Magnaporthe grisea Isolates of Finger Millet. Int.J.Curr.Microbiol.App.Sci. 8(08): 1830-1845.

doi: https://doi.org/10.20546/ijcmas.2019.808.216 